\title{
CIRCULATING RED CELL VOLUME MEASURED SIMULTANEOUSLY BY THE RADIOACTIVE IRON AND DYE METHODS ${ }^{1}$
}

\author{
By JOHN G. GIBSON, 2ND, WENDELL C. PEACOCK, ARNOLD M. SELIGMAN, AND \\ THEODORE SACK \\ (From the Radioactivity Center, Massachusetts Institute of Technology, Cambridge, Massachusetts; \\ the Medical Clinic of the Peter Bent Brigham Hospital, the Surgical Research Department \\ of the Beth Israel Hospital, and the Department of Medicine, \\ Harvard Medical School, Boston)
}

(Received for publication July 10, 1946)

The measurement of the circulating red cell volume is of considerable value in the study of the circulation in both the normal state and in experimentally induced abnormal circulatory states, and in disease. Modern modifications employing Evans Blue (T-1824) (1 to 3) of the original dye method of Keith et al (4) have clearly shown that plasma volume can be measured with a high degree of accuracy in normal man and animals. Values for normal plasma volume in man determined by several workers are in general agreement both as to absolute plasma volume and plasma volume per unit of body measurement $(2,5$ to 7$)$. The method has also proved reliable in the study of intravenous crystalloid (8) and colloid (9) therapy as well as in experimentally induced (10 to 12$)$ and clinical shock (7,12 to 14$)$. A recent improvement in the method described by Noble (15), in which changes in dye concentration of blood samples are corrected for variations in water content as determined by serum protein measurements, should increase the applicability of the technique.

There is no general agreement among authors that the dye plasma technique measures either the total or circulating red cell volume. The opinion that cell volume can be calculated from the determined plasma volume and the hematocrit of blood samples drawn from large arteries and veins or the auricle, is based on the assumption that the hematocrit of blood flowing through the entire vascular bed is a constant at all times and under all conditions. Smith (16) found lower values

\footnotetext{
1 The work described in this paper was done under a contract, recommended by the Committee on Medical Research, between the Office of Scientific Research and Development and the Massachusetts Institute of Technology, in collaboration with the Peter Bent Brigham Hospital and the Beth Israel Hospital, Boston.
}

for cell volume when measured by carbon monoxide than by dye. Ebert and Stead (17) found cell volume determined by the dye method lower than the predicted volume after hemorrhage and during subsequent hemodilution. On the basis of subsequent experiments, these authors (18) concluded that the cell plasma ratio of blood contained in minute vessels is lower than that of venous blood.

Hopper (19) simultaneously measured cell volume by the dye and carbon monoxide methods in 13 normal humans and 17 normal dogs. The ratio of values by the former to the latter method averaged 1.00 in the humans and 1.08 in the dogs. The range of ratios in individual cases was from 0.91 to 1.16 in man, and from 0.72 to 1.14 in the dogs, and in each series the number of cases with ratios less than unity was about equal to those with ratios greater than unity. They found the ratios to be even more variable in abnormal subjects (20).

Root et al (21) made similar observations, and found little difference between the "central arterial and body hematocrit."

The red cell volume was first measured by means of radioactive iron in dogs by Hahn and coworkers (22). They found the cell volume measured by the injection of tagged cells consistently lower than the dye plasma cell volume, by as much as from 10 to 40 per cent, averaging 25 per cent.

In the course of studies on the preservation of human blood (23) we had occasion to determine the circulating red cell volume of normal young males by means of radioactive iron, and in many instances dye-plasma volumes were performed simultaneously. Similar studies were also made in a large series of normal (stray) dogs. It seemed worth while to present these data, obtained in a 
large series of cases, since no similar studies have appeared in the literature.

\section{METHODS AND MATERIALS}

Plasma volume was determined by the method of Gibson and Evelyn (24). Blood samples were taken 10 minutes, and, in duplicate, 20 minutes after the injection of dye. Total blood volume and erythrocyte volume were calculated from the determined plasma volume and the venous hematocrit. Red cell volume was determined by the radioactive iron method (25). No correction was made for the injected donor cells (which are included in the cell volume when measured by radio-iron), since in most instances the quantity given was less than 2 per cent of the circulating cell volume. Donor cells were of Group $\mathrm{O}$ or $\mathrm{A}$, and were cross-matched with recipient's serum in each case. All recipients were $R h$ positive. Blood donors were prepared either with the 5-year half life isotope $\left(\mathrm{Fe}^{\mathrm{s5}}\right)$ or with the 47 -day half life isotope $\left(\mathrm{Fe}^{50}\right)$ but no donor had received both isotopes. Donor blood was drawn into acid citrate dextrose (ACD-G) (23) and refrigerated until used, and in no instance was the cell volume measured with donor blood that had stood (refrigerated) for more than 36 hours. Both Rh positive and $\mathrm{Rh}$ negative blood donors were used. The $\mathrm{Fe}{ }^{\mathrm{so}}$ donors had received their radioactive iron less than 100 days prior to the use of their cells in all instances.

Forty male medical students between 18 and 24 years of age volunteered for these studies. All had negative histories of blood dyscrasias, malaria, jaundice and recent acute infectious disease. No reactions following the injection of donor red cells occurred.

The recipient red cell unit activity due to the administration of tagged donor red cells (cpm. per ml. of red cells referred to the activity of a suitable standard of $\mathrm{Fe}^{\mathrm{ss}}$ or $\mathrm{Fe}^{\mathrm{s}}$ measured at the same time) varied little. In most cases sampling was continued for $\mathbf{5}$ days after transfusion. The constancy of these levels is shown in Table I, which gives recipient unit activities at 20 minutes, 1 and 4 hours after infusion, and at 24-hour intervals during the following 5 days. These data were obtained in $\mathbf{5}$ consecutive experiments. The extreme ranges of deviation were 9.5 per cent above and 14.1 per cent below the average value. Of the 40 observations in Table I, 32, or 80 per cent, were within \pm 5 per cent of the averages, and only 5 , or 12.5 per cent, were more than \pm 10 per cent of the averages. Hence the variations observed are for the most part within the probable error of the technique.

The plasma volume ( $\mathrm{Vpd})$, venous hematocrit, whole blood (Vwpd) and red cell volume (Vrpd) calculated from the plasma volume and hematocrit, the red cell volume determined by radio-iron ( $\mathrm{Vrr}$ ), and the sum of the plasma volume and radio-iron cell volume ( $\mathrm{Vwdr}$ ) are given in Table II. Also given is the ratio of the red cell volume as determined by radio-iron and dye-hematocrit (Vrr/Vrpd); and the body hematocrit, $\mathrm{Vrr} / \mathrm{Vwpd}$.

Red cell volume measurements were carried out simultaneously by both methods in 40 normal (stray) dogs. The dogs were of both sexes, and ranged in weight from 6.7 to $25.7 \mathrm{kgm}$. Fifteen animals were under nembutal anesthesia, and the rest were under light morphine narcosis. Results obtained are summarized in Table III.

\section{RESULTS}

In every case the value obtained for Vrr was less than that obtained for Vrpd. In the human series, the ratio Vrr/Vrpd showed extreme variations of from 0.70 to 0.95 , the average ratio being 0.845. The standard mean deviation of the series was 0.72 per cent, the individual deviation 4.5 per cent. Seventy-five per cent of the cases had a ratio within \pm 5 per cent of the average, and 90 per cent had a ratio within \pm 10 per cent of the average.

In the series of dogs the ratio $\mathrm{Vrr} / \mathrm{Vrpd}$ ranged from 0.62 to 0.98 , averaging 0.825 . The standard mean deviation of the series was 1.22 , the individual deviation 7.59 per cent. Twenty-three per cent of the cases gave a ratio between .60 and $.75 ; 39$ per cent, between .75 and .85 ; and 28 per cent, between .85 and 1.0 . The spread above and

TABLE I

Radioactivity* of recipient red cells following transfusion of cells tagged with $F^{60}$

\begin{tabular}{|c|c|c|c|c|c|c|c|c|c|c|c|}
\hline \multirow{3}{*}{$\begin{array}{l}\text { Exp. } \\
\text { no. }\end{array}$} & \multicolumn{8}{|c|}{ Days after transfusion } & \multirow{3}{*}{ Average } & \multirow{2}{*}{\multicolumn{2}{|c|}{ Extreme deviation }} \\
\hline & \multicolumn{3}{|c|}{ o } & \multirow{2}{*}{1} & \multirow{2}{*}{2} & \multirow{2}{*}{3} & \multirow{2}{*}{4} & \multirow{2}{*}{5} & & & \\
\hline & $20 \mathrm{~min}$. & $1 \mathrm{hr}$. & $4 \mathrm{hr}$. & & & & & & & & \\
\hline $\begin{array}{l}70 \\
71 \\
72 \\
73 \\
74\end{array}$ & $\begin{array}{l}.0207 \\
.0207 \\
.0234 \\
.0229 \\
.0403\end{array}$ & $\begin{array}{l}.0191 \\
.0213 \\
.0243 \\
.0218 \\
.0377\end{array}$ & $\begin{array}{l}.0214 \\
.0191 \\
.0246 \\
.0207 \\
.0425\end{array}$ & $\begin{array}{l}.0205 \\
.0228 \\
.0233 \\
.0233 \\
.0433\end{array}$ & $\begin{array}{l}.0203 \\
.0215 \\
.0219 \\
.0241 \\
.0433\end{array}$ & $\begin{array}{l}.0201 \\
.0226 \\
.0242 \\
.0229 \\
.0408\end{array}$ & $\begin{array}{l}.0206 \\
.0241 \\
.0223 \\
.0217 \\
.0405\end{array}$ & $\begin{array}{l}.0206 \\
.0241 \\
.0222 \\
.0232 \\
.0408\end{array}$ & $\begin{array}{l}.0204 \\
.0220 \\
.0231 \\
.0228 \\
.0413\end{array}$ & \begin{tabular}{c|}
+ per cent \\
4.9 \\
9.5 \\
5.3 \\
5.4 \\
4.8
\end{tabular} & $\begin{array}{c}- \text { per cent } \\
6.4 \\
13.2 \\
10.9 \\
14.1 \\
8.7\end{array}$ \\
\hline
\end{tabular}

* Expressed as Unit Activities = cpm per ml. of cells referred to cpm of a standard counted at the same time. 
TABLE II

Plasma and circulating red cell volume determined simultaneously by the dye and radio-iron methods. Normal males

\begin{tabular}{|c|c|c|c|c|c|c|c|c|c|c|c|c|c|}
\hline $\begin{array}{c}\text { Exp. } \\
\text { no. }\end{array}$ & Date & Age & Hght. & Wght. & $\begin{array}{c}\text { Surface } \\
\text { area }\end{array}$ & Vpd & $\begin{array}{c}\text { Venous } \\
\text { hct. }\end{array}$ & Vwpd & Vrpd & Vrr & Vwdr & $\begin{array}{l}\text { Vrr/ } \\
\text { Vrpd }\end{array}$ & $\begin{array}{l}\text { Body } \\
\text { hct. }\end{array}$ \\
\hline $\begin{array}{r}68 \\
69 \\
70 \\
72 \\
73 \\
75 \\
76 \\
77 \\
78 \\
79 \\
80 \\
81 \\
96 \\
97 \\
98 \\
99 \\
100 \\
101 \\
102 \\
103 \\
107 \\
108 \\
111 \\
113 \\
114 \\
148 \\
160 \\
162 \\
163 \\
164 \\
165 \\
167 \\
168 \\
169 \\
170 \\
172 \\
173 \\
175 \\
177 \\
178\end{array}$ & $\begin{array}{l}11-16-44 \\
11-17-44 \\
11-20-44 \\
11-24-44 \\
11-25-44 \\
11-30-44 \\
12-4-44 \\
12-5-44 \\
12-7-44 \\
12-8-44 \\
12-11-44 \\
12-12-44 \\
3-8-45 \\
3-13-45 \\
3-15-45 \\
3-20-45 \\
3-22-45 \\
3-7-45 \\
3-14-45 \\
3-12-45 \\
4-24-45 \\
4-25-45 \\
4-16-45 \\
5-7-45 \\
5-8-45 \\
8-13-45 \\
10-15-45 \\
10-22-45 \\
10-31-45 \\
10-29-45 \\
11-26-45 \\
12-3-45 \\
12-4-45 \\
12-11-45 \\
12-12-45 \\
2-27-46 \\
2-19-46 \\
2-25-46 \\
2-26-46 \\
2-21-46\end{array}$ & $\begin{array}{l}y r s . \\
23 \\
20 \\
18 \\
21 \\
20 \\
20 \\
23 \\
22 \\
22 \\
22 \\
23 \\
22 \\
20 \\
22 \\
21 \\
20 \\
24 \\
24 \\
20 \\
23 \\
21 \\
22 \\
23 \\
23 \\
22 \\
22 \\
23 \\
20 \\
22 \\
21 \\
20 \\
23 \\
23 \\
24 \\
23 \\
20 \\
21 \\
21 \\
20 \\
20\end{array}$ & $\begin{array}{l}c m . \\
172 \\
180 \\
180 \\
175 \\
183 \\
172 \\
175 \\
188 \\
183 \\
173 \\
187 \\
174 \\
173 \\
173 \\
173 \\
179 \\
176 \\
186 \\
183 \\
174 \\
173 \\
173 \\
178 \\
193 \\
183 \\
183 \\
198 \\
189 \\
188 \\
174 \\
181 \\
194 \\
181 \\
194 \\
174 \\
175 \\
180 \\
173 \\
175 \\
181\end{array}$ & $\begin{array}{l}\text { kgm. } \\
63.5 \\
69.0 \\
68.3 \\
72.5 \\
81.8 \\
66.0 \\
75.0 \\
78.4 \\
77.3 \\
65.4 \\
79.5 \\
63.5 \\
82.0 \\
63.3 \\
59.0 \\
65.5 \\
68.3 \\
84.2 \\
79.5 \\
70.2 \\
62.0 \\
89.0 \\
66.0 \\
80.0 \\
80.0 \\
80.0 \\
82.0 \\
84.3 \\
90.0 \\
66.0 \\
75.0 \\
84.2 \\
84.0 \\
89.0 \\
59.0 \\
66.0 \\
72.6 \\
84.3 \\
75.0 \\
76.5\end{array}$ & $\begin{array}{l}m \text { m* } \\
1.74 \\
1.86 \\
1.86 \\
1.86 \\
2.06 \\
1.77 \\
1.89 \\
2.03 \\
1.98 \\
1.77 \\
2.03 \\
1.76 \\
1.94 \\
1.76 \\
1.73 \\
1.82 \\
1.83 \\
2.08 \\
2.00 \\
1.83 \\
1.72 \\
2.06 \\
1.79 \\
2.08 \\
2.00 \\
2.00 \\
2.11 \\
2.10 \\
2.05 \\
1.82 \\
1.94 \\
2.12 \\
2.02 \\
2.18 \\
1.70 \\
1.78 \\
1.91 \\
1.97 \\
1.88 \\
1.96\end{array}$ & $\begin{array}{c}m l . \\
3110 \\
3650 \\
3850 \\
3490 \\
3930 \\
3310 \\
3850 \\
3360 \\
3330 \\
3580 \\
3320 \\
3540 \\
3520 \\
2480 \\
3370 \\
2930 \\
3070 \\
3700 \\
3430 \\
3220 \\
3180 \\
3930 \\
3390 \\
5000 \\
3850 \\
3850 \\
3740 \\
4110 \\
4180 \\
2790 \\
3230 \\
4680 \\
3400 \\
3660 \\
3200 \\
2780 \\
3980 \\
3660 \\
3800 \\
3620\end{array}$ & $\begin{array}{c}\text { per cent } \\
43.4 \\
43.5 \\
40.8 \\
41.9 \\
43.5 \\
39.2 \\
42.7 \\
42.7 \\
42.1 \\
40.1 \\
40.2 \\
42.8 \\
38.5 \\
43.6 \\
43.0 \\
44.5 \\
43.4 \\
40.0 \\
42.8 \\
41.2 \\
44.0 \\
39.7 \\
42.0 \\
39.1 \\
43.3 \\
44.2 \\
42.7 \\
45.1 \\
43.0 \\
42.9 \\
45.0 \\
39.3 \\
40.0 \\
41.0 \\
45.0 \\
48.1 \\
43.2 \\
47.8 \\
40.0 \\
42.5\end{array}$ & $\begin{array}{c}m l . \\
\mathbf{5 5 0 0} \\
6280 \\
6500 \\
6010 \\
6950 \\
5440 \\
6720 \\
\mathbf{5 8 6 0} \\
5740 \\
5980 \\
5550 \\
6190 \\
\mathbf{5 7 2 0} \\
4400 \\
5810 \\
5280 \\
5430 \\
6180 \\
6000 \\
5750 \\
5680 \\
6520 \\
5850 \\
8200 \\
6800 \\
6900 \\
6530 \\
7480 \\
7350 \\
4890 \\
5870 \\
7710 \\
5670 \\
6220 \\
5820 \\
5360 \\
7000 \\
7000 \\
6330 \\
6300\end{array}$ & $\begin{array}{c}m l . \\
2390 \\
2630 \\
2450 \\
2520 \\
3020 \\
2130 \\
2870 \\
2500 \\
2410 \\
2400 \\
2230 \\
2650 \\
2200 \\
1920 \\
2440 \\
2350 \\
2360 \\
2480 \\
2570 \\
2530 \\
2500 \\
2590 \\
2460 \\
3200 \\
2950 \\
3050 \\
2790 \\
3370 \\
3170 \\
2100 \\
2640 \\
3030 \\
2270 \\
2560 \\
2620 \\
2580 \\
3020 \\
3340 \\
2530 \\
2680\end{array}$ & $\begin{array}{c}m l . \\
1990 \\
2100 \\
1850 \\
2040 \\
2450 \\
1810 \\
2000 \\
2380 \\
2140 \\
2040 \\
2110 \\
2150 \\
1760 \\
1610 \\
1990 \\
2010 \\
2000 \\
2260 \\
2100 \\
2050 \\
2120 \\
2200 \\
2000 \\
2760 \\
2600 \\
2480 \\
2340 \\
2910 \\
2860 \\
1870 \\
2290 \\
2540 \\
1970 \\
2160 \\
2140 \\
2180 \\
2530 \\
2920 \\
2270 \\
2350\end{array}$ & $\begin{array}{c}m l . \\
5100 \\
5750 \\
5700 \\
5530 \\
6380 \\
5120 \\
5850 \\
5740 \\
5470 \\
5620 \\
5430 \\
5690 \\
5280 \\
4090 \\
5360 \\
4940 \\
5070 \\
5960 \\
5530 \\
5270 \\
5300 \\
6130 \\
5390 \\
7760 \\
6450 \\
6330 \\
6080 \\
7020 \\
7040 \\
4660 \\
5520 \\
7220 \\
5370 \\
5820 \\
5340 \\
4960 \\
6510 \\
6580 \\
6070 \\
5970\end{array}$ & $\begin{array}{l}0.83 \\
0.79 \\
0.76 \\
0.81 \\
0.81 \\
0.85 \\
0.70 \\
0.95 \\
0.89 \\
0.85 \\
0.95 \\
0.81 \\
0.80 \\
0.84 \\
0.82 \\
0.86 \\
0.85 \\
0.91 \\
0.82 \\
0.81 \\
0.85 \\
0.85 \\
0.82 \\
0.86 \\
0.88 \\
0.81 \\
0.84 \\
0.86 \\
0.90 \\
0.86 \\
0.87 \\
0.84 \\
0.87 \\
0.84 \\
0.82 \\
0.85 \\
0.84 \\
0.88 \\
0.89 \\
0.88\end{array}$ & $\begin{array}{l}39.1 \\
36.5 \\
32.4 \\
36.9 \\
38.4 \\
35.4 \\
34.2 \\
41.4 \\
39.1 \\
36.3 \\
38.9 \\
37.8 \\
33.3 \\
39.3 \\
37.2 \\
40.6 \\
39.6 \\
37.9 \\
38.0 \\
38.9 \\
40.0 \\
35.8 \\
40.8 \\
35.6 \\
40.3 \\
39.1 \\
38.5 \\
41.5 \\
40.7 \\
40.0 \\
41.4 \\
35.2 \\
36.7 \\
37.2 \\
40.1 \\
43.9 \\
38.9 \\
44.3 \\
37.4 \\
39.4\end{array}$ \\
\hline \multicolumn{2}{|c|}{ Average } & & & & & & 42.44 & & & & & 0.845 & 38.44 \\
\hline
\end{tabular}

* From Nomograms of Boothby and Sandiford.

Key: $\quad$ Vpd $=$ Volume of plasma by dye method

Vwpd = Volume of whole blood by dye method

Vrpd = Volume of red cells by dye method

Vrr $=$ Volume of red cells by radio-iron method

$\mathrm{Vwdr}=$ Total blood volume (Vpd + Vrr)

below the average was wider than in the human series.

This ratio, in individual cases, bore no relationship to venous hematocrit, or to absolute plasma volume or red cell volume (by radio-iron), as shown in Figure 1 for the normal males, and in Figure 2 for the dogs.

The body hematocrit ( $\mathrm{Vrr} / \mathrm{Vwdr}$ ) in every case was lower than that of the venous hematocrit. The average of the body hematocrits was 38.3, that of the venous hematocrits being 42.5 in hu- mans, and corresponding values were 41.6 and 46.8 in dogs. The ratio of body to venous hematocrit was 0.91 in the 2 series. Thus the body hematocrit is lower than the venous hematocrit by about 10 per cent. Since the ratio Vrr/Vrpd is an expression of the relationship of circulating cell volume to both plasma volume and hematocrit, it follows that the body hematocrit is independent of both the absolute plasma volume and hematocrit level.

Eight dogs were subjected to hemorrhages large 
enough to produce considerable lowering of jugular hematocrits, but not to cause peripheral collapse over a period of a few hours to 3 days. Red cell volumes were measured by both methods simultaneously before bleeding and after hemodilution occurred. Four of the dogs were splenectomized. The data obtained are given in Table IV. The ratio Vrr/Vrpd was less than unity in all 20 determinations, ranging from 0.62 to 0.98 and averaging 0.82 . Here again there was no correlation between the ratio $\mathrm{Vrr} / \mathrm{Vrpd}$ and jugular hematocrit level.

Qualitatively similar observations were made in 2 patients in whom red cell volume was meas- ured by both methods before and after transfusions of whole blood, and in 2 patients before and after phlebotomy (Table IV).

The relationship of normal blood volume to physical measurements is beyond the scope of this paper, and will be discussed in a subsequent communication.

\section{DISCUSSION}

The data presented consistently show that the circulating red cell volume, when determined by the radio-iron technique, is some $\mathbf{1 5}$ per cent less than when determined by the dye-plasma-hematocrit technique. A wider spread in individual val-

TABLE III

Plasma and circulating red cell volume determined simultaneously by the dye and radio-iron methods. Normal (stray) dogs

\begin{tabular}{|c|c|c|c|c|c|c|c|c|c|c|c|}
\hline \multirow{2}{*}{ Exp. no. } & \multirow{2}{*}{ Date } & \multirow{2}{*}{ Wght. } & \multirow{2}{*}{ Vpd } & \multirow{2}{*}{$\begin{array}{c}\text { Venous } \\
\text { hct. }\end{array}$} & \multirow{2}{*}{ Vwpd } & \multirow{2}{*}{ Vrpd } & \multirow{2}{*}{ Vrr } & \multirow{2}{*}{ Vwdr } & \multirow{2}{*}{ Vrr/Vrpd } & \multirow{2}{*}{$\begin{array}{l}\text { Body } \\
\text { hct. }\end{array}$} & $\begin{array}{l}\text { Body } \\
\text { hct. }\end{array}$ \\
\hline & & & & & & & & & & & $\begin{array}{c}\text { Venous } \\
\text { hct. }\end{array}$ \\
\hline $\begin{array}{l}131-4 \\
131-6 \\
131-7 \\
131-39 \\
131-40 \\
131-41 \\
135-7 \\
135-8 \\
135-9 \\
135-11 \\
135-15 \\
135-16 \\
135-89 \\
135-90 \\
135-96 \\
135-134 \\
135-136 \\
21-13 \\
21-23 \\
21-29 \\
21-41 \\
21-42 \\
21-45 \\
21-102 \\
21-104 \\
21-105 \\
21-109 \\
21-113 \\
21-114 \\
21-117 \\
21-118 \\
21-119 \\
21-120 \\
21-121 \\
21-129 \\
21-130 \\
21-131 \\
21-132 \\
5 A-2 \\
5 A-3 \\
\end{array}$ & $\begin{array}{l}2-19-42 \\
2-26-42 \\
4-16-42 \\
3-10-42 \\
3-17-42 \\
3-25-42 \\
7-22-42 \\
7-29-42 \\
7-29-42 \\
8-5-42 \\
8-19-42 \\
8-26-42 \\
2-11-43 \\
2-11-43 \\
2-18-43 \\
4-27-43 \\
4-29-43 \\
5-25-42 \\
5-25-42 \\
5-8-42 \\
6-18-42 \\
6-18-42 \\
6-18-42 \\
7-13-42 \\
7-30-42 \\
7-30-42 \\
10-13-42 \\
12-8-42 \\
12-22-42 \\
1-6-43 \\
3-8-43 \\
3-24-43 \\
3-30-43 \\
4-1-43 \\
10-8-43 \\
10-19-43 \\
11-8-43 \\
12-8-43 \\
11-3-43 \\
11-17-43\end{array}$ & $\begin{array}{r}\text { kgm. } \\
\\
14.2 \\
13.0 \\
13.6 \\
18.2 \\
25.7 \\
20.0 \\
16.5 \\
15.5 \\
15.3 \\
17.5 \\
21.4 \\
21.0 \\
14.0 \\
16.5 \\
13.5 \\
9.3 \\
25.0 \\
19.0 \\
7.3 \\
16.1 \\
14.2 \\
18.0 \\
9.0 \\
10.7 \\
9.3 \\
8.6 \\
18.4 \\
18.6 \\
20.5 \\
17.5 \\
16.8 \\
18.0 \\
12.0 \\
10.4 \\
10.9 \\
11.8 \\
16.4 \\
6.7 \\
9.0\end{array}$ & $\begin{array}{r}m l . \\
1015 \\
670 \\
620 \\
630 \\
1105 \\
1415 \\
1500 \\
1100 \\
1300 \\
765 \\
780 \\
1000 \\
910 \\
730 \\
975 \\
770 \\
390 \\
1125 \\
1235 \\
370 \\
800 \\
810 \\
1060 \\
475 \\
480 \\
400 \\
380 \\
945 \\
795 \\
1110 \\
990 \\
910 \\
1130 \\
615 \\
570 \\
640 \\
680 \\
915 \\
515 \\
285\end{array}$ & $\begin{array}{c}\text { per cent } \\
43.1 \\
50.8 \\
49.3 \\
50.4 \\
45.7 \\
47.1 \\
41.0 \\
32.1 \\
40.0 \\
47.7 \\
47.4 \\
47.0 \\
51.3 \\
48.0 \\
48.2 \\
44.9 \\
52.6 \\
61.3 \\
38.9 \\
45.0\end{array}$ & $\begin{array}{r}\text { ml. } \\
1780 \\
1360 \\
1220 \\
1270 \\
2035 \\
2670 \\
2540 \\
1620 \\
2170 \\
1465 \\
1480 \\
1890 \\
1870 \\
1400 \\
1880 \\
1400 \\
820 \\
2905 \\
2025 \\
675 \\
1560 \\
1215 \\
1760 \\
395 \\
880 \\
800 \\
745 \\
1770 \\
1480 \\
2070 \\
2080 \\
1600 \\
1930 \\
1050 \\
1430 \\
1220 \\
1165 \\
1800 \\
870 \\
595\end{array}$ & $\begin{array}{r}m l . \\
765 \\
690 \\
600 \\
640 \\
930 \\
1255 \\
1140 \\
520 \\
870 \\
700 \\
700 \\
890 \\
960 \\
670 \\
905 \\
630 \\
570 \\
1780 \\
790 \\
305 \\
760 \\
405 \\
700 \\
870 \\
400 \\
400 \\
365 \\
825 \\
685 \\
960 \\
1090 \\
690 \\
800 \\
435 \\
860 \\
580 \\
585 \\
885 \\
370 \\
310\end{array}$ & $\begin{array}{r}m l . \\
570 \\
645 \\
560 \\
600 \\
630 \\
980 \\
1000 \\
450 \\
790 \\
550 \\
625 \\
665 \\
680 \\
645 \\
675 \\
525 \\
385 \\
1090 \\
620 \\
250 \\
740 \\
320 \\
465 \\
315 \\
325 \\
300 \\
335 \\
780 \\
620 \\
830 \\
890 \\
550 \\
680 \\
360 \\
670 \\
440 \\
440 \\
710 \\
330 \\
290\end{array}$ & $\begin{array}{r}m l . \\
1585 \\
1360 \\
1180 \\
1230 \\
1735 \\
2395 \\
2500 \\
1550 \\
2090 \\
1315 \\
1405 \\
1665 \\
1590 \\
1375 \\
1650 \\
1295 \\
775 \\
2215 \\
1855 \\
620 \\
1540 \\
1130 \\
1525 \\
790 \\
805 \\
700 \\
715 \\
1725 \\
1415 \\
1940 \\
1880 \\
1460 \\
1810 \\
975 \\
1240 \\
1080 \\
1120 \\
1625 \\
845 \\
575\end{array}$ & $\begin{array}{l}0.75 \\
0.93 \\
0.93 \\
0.94 \\
0.68 \\
0.78 \\
0.88 \\
0.87 \\
0.91 \\
0.79 \\
0.89 \\
0.75 \\
0.71 \\
0.97 \\
0.75 \\
0.84 \\
0.68 \\
0.62 \\
0.79 \\
0.82 \\
0.98 \\
0.79 \\
0.67 \\
0.80 \\
0.82 \\
0.75 \\
0.89 \\
0.95 \\
0.91 \\
0.87 \\
0.82 \\
0.80 \\
0.85 \\
0.83 \\
0.78 \\
0.76 \\
0.75 \\
0.80 \\
0.89 \\
0.94\end{array}$ & $\begin{array}{c}\text { per cent } \\
35.9 \\
47.3 \\
47.3 \\
48.7 \\
36.6 \\
40.7 \\
40.0 \\
29.0 \\
37.8 \\
41.7 \\
44.3 \\
39.9 \\
42.8 \\
46.9 \\
40.8 \\
40.6 \\
49.8 \\
49\end{array}$ & $\begin{array}{l}.83 \\
.93 \\
.96 \\
.96 \\
.80 \\
.87 \\
.97 \\
.90 \\
.95 \\
.88 \\
.94 \\
.85 \\
.84 \\
.98 \\
.85 \\
.91 \\
.95 \\
.80 \\
.86 \\
.90 \\
.98 \\
.85 \\
.77 \\
.88 \\
.90 \\
.86 \\
.93 \\
.96 \\
.95 \\
.91 \\
.98 \\
.95 \\
.91 \\
.76 \\
.90 \\
.86 \\
.95 \\
.86 \\
.93 \\
.97\end{array}$ \\
\hline Average & & & & 46.8 & & & & & 0.823 & 41.6 & 0.91 \\
\hline
\end{tabular}




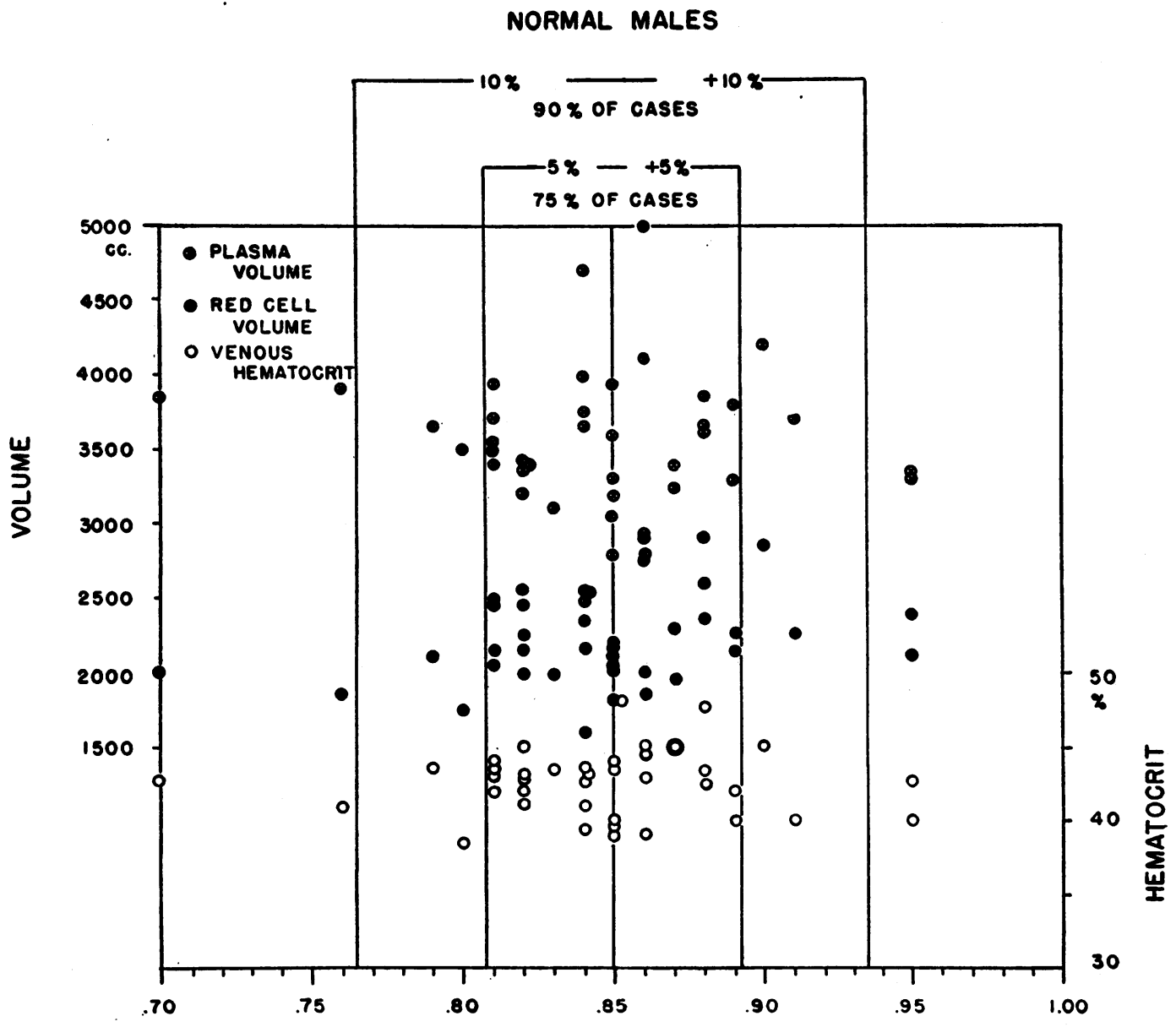

VRR / VRPO

Fig. 1. The Relationship of Plasma Volume and Red Cell Volume of Venous Hematocrit to the Ratio of Red Cell Volume, as Determined by the Radio-iron and Dye Methods

ues was encountered in the dogs than in the humans. These dogs were in varying states of nutrition and their past histories were unknown. Hahn (26) made similar observations in 8 normal dogs, in which the ratio of radio-iron to dye plasma red cell volume ranged from 0.64 to 0.91 , averaging 0.79 .

Hahn and Meneely (27) more recently carried out blood volume studies by the dye and radioiron methods in 28 hospitalized patients, ${ }^{2}$ with venous hematocrits ranging from 27.3 per cent to 50.6 per cent. In only 2 cases was the radio-iron cell volume higher than the dye-hematocrit cell volume, the average of the ratios thereof being

2 The authors state "these patients were not normals, but people in various stages of disease or convalescence."
0.81. The average of the body hematocrits was 31.4 , and the average of the venous hematocrits was 39.7 , the ratio being 0.79 , considerably lower than in our series. Both of these studies are, however; in keeping with our findings.

The values obtained by the radio-iron method are independent of variations in the hematocrit of blood samples drawn from large vessels, whereas the venous or arterial hematocrit is the basis of the calculation of red cell volume in the dye method. The consistent discrepancy in results obtained by the 2 methods requires that a decision as to which method most accurately measures the true circulating red cell volume be made.

The validity of the radio-iron technique rests on 2 assumptions, (1) that all of the tagged donor 
red cells remain intact throughout the period of significant observation, and (2) that all of the tagged cells become completely mixed with all of the recipient's cells within the vascular bed.

The donor cells used in these experiments were drawn in the best known blood preservative and, if not transfused immediately, were refrigerated until used. Under these circumstances little, if any, change in corpuscular measurements or in osmotic fragility occurs for at least 48 hours.

Hawkins and Whipple (28) estimated the normal life span of the canine red cell. Massive hemolysis was produced by phenylhydrazine, and this was followed by rapid regeneration of erythrocytes to a normal level over a 10 to 30 day period. Urobilinogen output fell off sharply during this period, and remained low until 100 to 120 days after cell regeneration had begun, when it rose abruptly, the rise being maintained for a period about equal to that during which regeneration had taken place. This rise was attributed to the destruction of the cells regenerated after phenylhydrazine poisoning.

Shemin and Rittenberg (29) fed glycine tagged with $\mathrm{N}^{15}$ and found it resulted in the formation of heme with a high concentration of the isotope. They followed the $\mathrm{N}^{15}$ concentration of heme in human red cells for several months and concluded that the average life time of the erythrocyte is about 125 days.

Ashby (30) determined the life span of fresh red cells as being from 100 to 130 days by the agglutination method, in which Group $\mathrm{O}$ cells are injected into Group A recipients. These results have been repeatedly confirmed ( 31 to 35 ). There can be little doubt that freshly drawn compatible donor cells have their full life expectancy when administered to a recipient.

The second assumption is supported by the data presented in Table I. The recipients of these infusions of fresh Group $\mathrm{O}$ cells were leading normal daily lives : eating, exercising, and sleeping. The

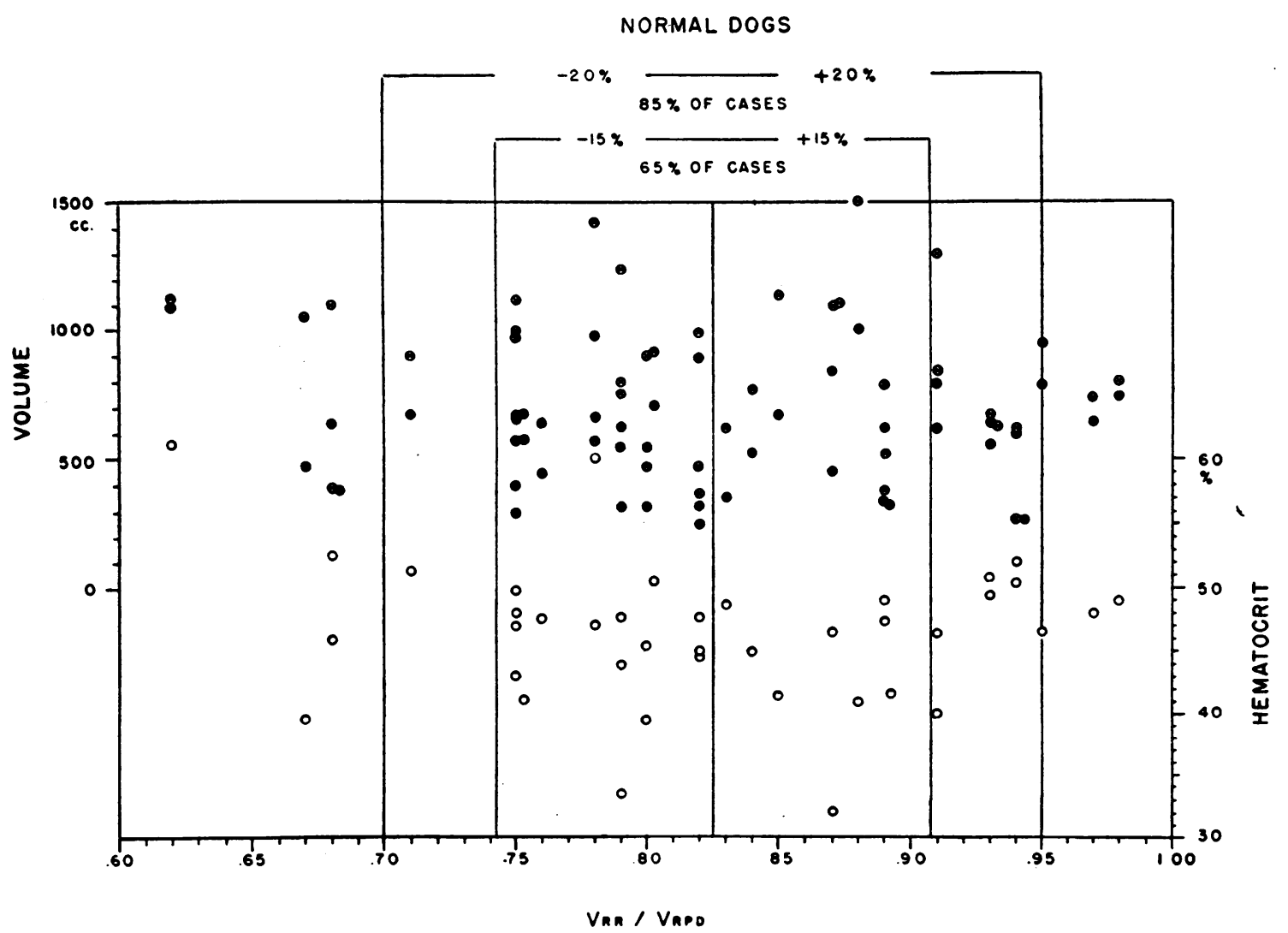

Fig. 2. The Relationship of Plasma Volume and Red Cell Volume of Venous Hematocrit to the Ratio of Red Cell Volume, as Determined by the Radio-iron and Dye Methods 
TABLE IV

Red cell volume measured by the radio-iron and dye method before and after bleeding and transfusion. Eight dogs undergoing repeated hemorrhage

\begin{tabular}{|c|c|c|c|c|c|c|c|c|c|}
\hline \multicolumn{2}{|c|}{ Experiment no. } & \multirow{2}{*}{$\begin{array}{c}\text { Vpd } \\
m l . \\
1015 \\
985\end{array}$} & \multirow{2}{*}{$\begin{array}{c}\text { Venous hct. } \\
\text { per cent } \\
43.1 \\
33.7\end{array}$} & \multirow{2}{*}{$\begin{array}{c}\text { Vwpd } \\
m l . \\
1780 \\
1480\end{array}$} & \multirow{2}{*}{$\begin{array}{l}\text { Vrpd } \\
m l . \\
765 \\
495\end{array}$} & \multirow{2}{*}{$\begin{array}{l}\text { Vrr } \\
m l . \\
570 \\
535\end{array}$} & \multirow{2}{*}{$\begin{array}{c}\text { Vrr/Vrpd } \\
\\
0.75 \\
0.76\end{array}$} & \multirow{2}{*}{$\begin{array}{c}\text { Body het. } \\
\text { per cent } \\
32.0 \\
26.0\end{array}$} & \multirow{2}{*}{$\begin{array}{c}\text { Body hct. } \\
\text { Venous hct. } \\
.74 \\
.77\end{array}$} \\
\hline $131-4$ & Spleen intact & & & & & & & & \\
\hline $131-6$ & Spleen intact & $\begin{array}{l}670 \\
725\end{array}$ & $\begin{array}{l}50.8 \\
41.3\end{array}$ & $\begin{array}{l}1390 \\
1240\end{array}$ & $\begin{array}{l}720 \\
515\end{array}$ & $\begin{array}{l}645 \\
500\end{array}$ & $\begin{array}{l}0.89 \\
0.97\end{array}$ & $\begin{array}{l}46.3 \\
40.3\end{array}$ & $\begin{array}{l}.91 \\
.98\end{array}$ \\
\hline $131-7$ & Spleen intact & $\begin{array}{l}620 \\
630 \\
780\end{array}$ & $\begin{array}{l}49.3 \\
28.3 \\
27.6\end{array}$ & $\begin{array}{r}1220 \\
880 \\
1080\end{array}$ & $\begin{array}{l}600 \\
250 \\
300\end{array}$ & $\begin{array}{l}560 \\
240 \\
240\end{array}$ & $\begin{array}{l}0.93 \\
0.96 \\
0.81\end{array}$ & $\begin{array}{l}45.8 \\
27.3 \\
22.2\end{array}$ & $\begin{array}{l}.93 \\
.97 \\
.81\end{array}$ \\
\hline $21-13$ & Splenectomized & $\begin{array}{r}1125 \\
785 \\
1110\end{array}$ & $\begin{array}{l}61.3 \\
56.5 \\
42.9\end{array}$ & $\begin{array}{l}2900 \\
1810 \\
1940\end{array}$ & $\begin{array}{r}1775 \\
1025 \\
830\end{array}$ & $\begin{array}{r}1090 \\
770 \\
730\end{array}$ & $\begin{array}{l}0.62 \\
0.75 \\
0.88\end{array}$ & $\begin{array}{l}37.6 \\
42.3 \\
37.6\end{array}$ & $\begin{array}{l}.61 \\
.75 \\
.88\end{array}$ \\
\hline $21-18$ & Spleen intact & $\begin{array}{r}870 \\
1255\end{array}$ & $\begin{array}{l}49.5 \\
36.3\end{array}$ & $\begin{array}{l}1720 \\
1970\end{array}$ & $\begin{array}{l}850 \\
715\end{array}$ & $\begin{array}{l}620 \\
480\end{array}$ & $\begin{array}{l}0.73 \\
0.67\end{array}$ & $\begin{array}{l}37.1 \\
24.3\end{array}$ & $\begin{array}{l}.73 \\
.67\end{array}$ \\
\hline $21-23$ & Splenectomized & $\begin{array}{r}1235 \\
1140 \\
930\end{array}$ & $\begin{array}{l}38.9 \\
37.6 \\
31.3\end{array}$ & $\begin{array}{l}2020 \\
1825 \\
1350\end{array}$ & $\begin{array}{l}785 \\
685 \\
420\end{array}$ & $\begin{array}{l}620 \\
530 \\
410\end{array}$ & $\begin{array}{l}0.79 \\
0.78 \\
0.98\end{array}$ & $\begin{array}{l}30.3 \\
28.9 \\
30.4\end{array}$ & $\begin{array}{l}.78 \\
.77 \\
.97\end{array}$ \\
\hline $21-42$ & Splenectomized & $\begin{array}{l}810 \\
750 \\
875\end{array}$ & $\begin{array}{l}33.4 \\
32.5 \\
27.0\end{array}$ & $\begin{array}{l}1210 \\
1110 \\
1200\end{array}$ & $\begin{array}{l}400 \\
360 \\
325\end{array}$ & $\begin{array}{l}320 \\
265 \\
265\end{array}$ & $\begin{array}{l}0.80 \\
0.74 \\
0.82\end{array}$ & $\begin{array}{l}26.4 \\
23.9 \\
22.1\end{array}$ & $\begin{array}{l}.79 \\
.74 \\
.82\end{array}$ \\
\hline $21-45$ & Splenectomized & $\begin{array}{r}1060 \\
590\end{array}$ & $\begin{array}{l}39.7 \\
31.6\end{array}$ & $\begin{array}{r}1760 \\
865\end{array}$ & $\begin{array}{l}700 \\
275\end{array}$ & $\begin{array}{l}465 \\
200\end{array}$ & $\begin{array}{l}0.67 \\
0.73\end{array}$ & $\begin{array}{l}26.4 \\
23.1\end{array}$ & $\begin{array}{l}.67 \\
.73\end{array}$ \\
\hline Average & & & & & & & 0.81 & & 0.77 \\
\hline
\end{tabular}

Two polycythemic patients undergoing phlebotomy *

\begin{tabular}{c|c|c|c|c|c|c|c|c|c}
\hline CR-1 & 2510 & 59.8 & 6270 & 3760 & 2930 & 0.78 & 53.8 & 0.90 \\
& & 2750 & 55.2 & 6130 & 2510 & 2510 & 0.75 & 47.7 & 0.87 \\
CR-4 & & 3230 & 55.2 & 7340 & 4110 & 3640 & 0.89 & 53.3 & 0.97 \\
\hline Average & & 2800 & 54.7 & 6160 & 3360 & 2630 & 0.79 & 48.3 & 0.89 \\
\hline
\end{tabular}

Two patients receiving whole blood transfusions

\begin{tabular}{c|c|c|c|c|c|c|c|c|c}
\hline O-O & Acute hemorrhage & 4920 & 10.7 & 5500 & 580 & 510 & 0.88 & 9.3 & 0.87 \\
& & 4680 & 15.4 & 5530 & 850 & 800 & 0.94 & 14.4 & 0.94 \\
A-D & Hemolytic anemia & 2780 & 24.5 & 3690 & 910 & 825 & 0.91 & 22.3 & 0.91 \\
& & 2600 & 41.4 & 4440 & 1840 & 1590 & 0.87 & 36.8 & 0.89 \\
\hline Average & & & & & & & & & \\
\hline
\end{tabular}

* These experiments were carried out in collaboration with Dr. A. Cournand at Bellevue Hospital, N. Y. C.

constancy of their red cell radioactivity levels precludes the possibility that any considerable portion of their own cells (with the possible exception of immature cells in marrow) were in vascular areas into which the tagged cells had not entered, since the influx of any considerable quantity of such cells would have lowered the circulating red cell radioactivity levels of these individuals. The fact that initial radioactivity levels closely approximated the averages of the levels over a 6-day period is proof that mixing of tagged with nontagged cells was complete within 20 minutes after injection.

Further proof of complete mixing of tagged 
with all of the non-tagged cells lies in the observation that the unit activity of a recipient's red cells is neither raised nor lowered by the brisk removal of a large quantity (20 per cent) of total circulating red cell volume, and that the amount of cells removed is accurately measured (to within 5 per cent) by a subsequent volume determination involving the injection of a further quantity of tagged cells. Likewise, radio-iron cell volume determinations, before and after large transfusions of non-tagged red cells, do accurately measure amounts of cells given (25).

Our findings are in agreement with those of Hahn (22), who found little change, over periods of from 3 to 8 days, in the red cell radioactivity of red cells in dogs who had received tagged erythrocytes.
If it be accepted that the true circulating red cell volume is accurately measured by the radioiron technique, then the consistently higher volume found by the dye plasma technique must be due to differences in the hematocrit of blood within large and small vessels.

We have found the body hematocrit to be about nine-tenths of the large vessel hematocrit. This implies that the hematocrit of some portion of the total vascular content must have an hematocrit even lower than the body hematocrit.

Direct observations on the hematocrit of minute vessel blood are few, largely because of the technical difficulties of obtaining true capillary blood. Ebert (18) obtained blood from both large and small vessels of the forearm of human subjects. Arterial flow to the extremity was first

RELATIONSHIP OF BODY TO VENOUS HEMATOCRIT

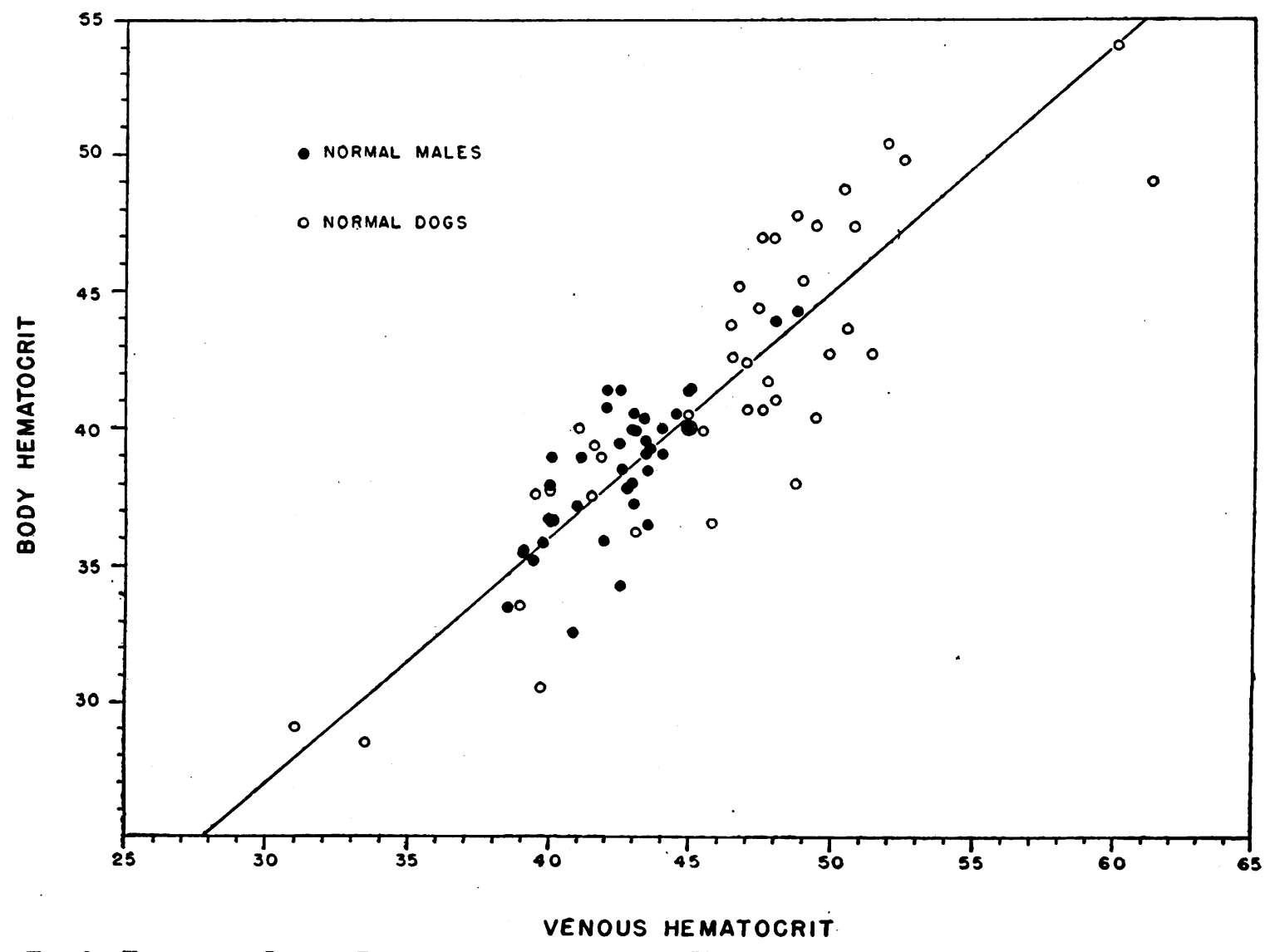

Fig. 3. There is a Linear Relationship Between the Hematocrit of All the Blood of the Body and Blood Obtained by Venous Sampling 
occluded. Blood was then removed from a large vein until no more could be obtained. An Esmarch's bandage was then applied and additional blood from minute vessels was squeezed out. A comparison of the cellular content of the large and minute vessel blood was made on the basis of hemoglobin content. In 15 experiments the average hemoglobin content of the minute vessel blood was 13.2 grams per $100 \mathrm{ml}$., while that of the large vessels was 14.3 grams per $100 \mathrm{ml}$., the ratio being 0.9 . Since some of the blood obtained by the final squeezing may have come from vessels larger than true capillaries, the hematocrit of very minute vessel blood may well be lower than the above ratio would indicate.

It is of interest to speculate to what extent the ratio of body to large vessel hematocrit remains constant at varying hematocrit levels. Hahn (36) found a linear relationship between jugular hematocrit and circulating red cell mass as determined by radioactive iron in individual dogs, within a range of from 11 to 57 . This relationship may be expressed as the ratio of body to venous hematocrit. In both of our series there is a good correlation between body and venous hematocrit, within a range of from 38 to 48 for humans, and from 32.1 to 61.3 for dogs, as shown in Figure 3.

Thus it appears probable that the proportion of blood in large and minute vessels, and the hematocrits of the blood flowing through those compartments both remain fairly constant, within fairly narrow limits, under normal conditions. Direct evidence that this is the case will be presented in a further publication (37).

The significance of these findings is worthy of comment. The actual quantities of red cells involved in the intrinsic error of the dye plasma technique are not inconsiderable, ranging from 100 to $600 \mathrm{ml}$. in individual cases (Table II). This discrepancy is probably not too serious from a clinical diagnostic point of view, since the significant changes of cell volume in disease are frequently of a greater order. They do, however, become significant in clinical investigation, particularly in circulatory disturbances where the normal distribution of cells in large and minute vessels may be considerably disturbed.

\section{CONCLUSIONS}

1. Circulating red cell volume was determined by both the radioactive iron and dye-plasma methods in 40 normal males and 40 normal (stray) dogs.

2. The ratio of the radio-iron to the dye-plasma red cell volume averaged 0.85 in humans and 0.82 in dogs.

3. The ratio of average body hematocrit to large vessel hematocrit averaged 0.91 in both series.

4. There is no relationship of either ratio to absolute plasma volume or large vessel hematocrit.

5. There is a linear relationship of body hematocrit to large vessel hematocrit.

6. The probability that the hematocrit of minute vessel blood is less than the body hematocrit is discussed.

\section{BIBLIOGRAPHY}

1. Gibson, J. G., 2nd, and Evans, W. A., Jr., Clinical studies of the blood volume. I. Clinical application of a method employing the azo dye "Evans Blue" and the spectrophotometer. J. Clin. Invest., 1937, $16,301$.

2. Davis, L. J., Determination of blood volume in man with "Evans" Blue ("T-1824"). Edinburgh M. J., 1942, 49, 465.

3. Gregersen, M. I., A practical method for the determination of blood volume with the dye T-1824. J. Lab. and Clin. Med., 1944, 29, 1266.

4. Keith, N. M., Rowntree, L. G., and Geraghty, J. T., A method for the determination of plasma and blood volume. Arch. Int. Med., 1915, 16, 547.

5. Gibson, J. G., 2nd, and Evans, W. A., Jr., Clinical studies of the blood volume. II. The relation of plasma and total blood volume to venous pressure, blood velocity rate, physical measurements, age and sex in ninety normal humans. J. Clin. Invest., 1937, 16, 317.

6. Stewart, J. D., and Rourke, G. M., On the measurement of extracellular fluid volume with thiocyanate and body fluid analyses in 33 normal individuals. J. Lab. and Clin. Med., 1941, 26, 1383.

7. Noble, R. P., and Gregersen, M. I., Blood volume in clinical shock. II. The extent and cause of blood volume reduction in traumatic, hemorrhagic, and burn shock. J. Clin. Invest., 1946, 25, 172.

8. Gilligan, D. R., Altschule, M. D., and Katresky, E. M., Studies of hemoglobinemia and hemoglobinuria produced in man by intravenous injection of hemoglobin solutions. J. Clin. Invest., 1941, 20, 177.

9. Heyl, J. T., Gibson, J. G., 2nd, and Janeway, C. A., Studies on the plasma proteins. V. The effect of concentrated solutions of human and bovine serum albumin on blood volume after acute blood loss in man. J. Clin. Invest., 1943, 22, 763.

10. Keeley, J. L., Gibson, J. G., 2nd, and Pijoan, M., The effect of thermal trauma on blood volume, serum protein, and certain blood electrolytes: An experimental study of the effect of burns. Surgery, 1939, 5,872 . 
11. Fine, J., and Seligman, A. M., Traumatic shock: IV. A study of the problem of the "lost plasma" in hemorrhagic shock by the use of radioactive plasma protein. J. Clin. Invest., 1943, 22, 285.

12. Evans, E. I., Hoover, M. J., James, G. W., and Alm, T., Studies on traumatic shock. I. Blood volume changes in traumatic shock. Ann. Surg., 1944, 119, 64.

13. Richards, D. W., Jr., The circulation in traumatic shock in man. The Harvey Lectures, 1943-1944, p. 217. The Science Press Printing Company, Lancaster, $\mathrm{Pa}$.

14. Warren, J. V., Stead, E. A., Jr., Merrill, A. J., and Brannon, E. S., The treatment of shock with concentrated human serum albumin. J. Clin. Invest., 1944, 23, 506.

15. Noble, R. P., and Gregersen, M.'I., Blood volume in clinical shock. I. Mixing time and disappearance rate of $T-1824$ in normal subjects and in patients in shock; determination of plasma volume in man from 10-minute sample. J. Clin. Invest., 1946, 25, 158.

16. Smith, H. P., Arnold, H. R., and Whipple, G. H., Blood volume studies. VII. Comparative values of Welcker, carbon monoxide and dye methods for blood volume determinations. Am. J. Physiol., 1921, 56, 336.

17. Ebert, R. V., Stead, E. A., Jr., and Gibson, J. G., II, Response of normal subjects to acute blood loss with special reference to the mechanism of restoration of blood volume. Arch. Int. Med., 1941, 68, 578.

18. Ebert, R. V., and Stead, E. A., Jr., Demonstration that the cell plasma ratio of blood contained in minute vessels is lower than that of venous blood. J. Clin. Invest., 1941, 20, 317.

19. Hopper, J., Jr., Tabor, H., and Winkler, A. W., Simultaneous measurements of the blood volume in man and dog by means of Evans blue dye, $\mathrm{T}-1824$, and by means of carbon monoxide. I. Normal subjects. J. Clin. Invest., 1944, 23, 628.

20. Hopper, J., Jr., Winkler, A. W., and Elkinton, J. R., Simultaneous measurements of the blood volume in man and dog by means of Evans blue dye, T-1824, and by means of carbon monoxide. II. Under abnormal conditions, including secondary shock. J. Clin. Invest., 1944, 23, 636.

21. Root, W. S., Roughton, F. J. W., and Gregersen, M. I., Simultaneous measurement of blood volume with dye (T-1824) and with carbon monoxide. Proc. Am. Physiol. Soc., 1945, 4, 60.

22. Hahn, P. F., Ross, J. F., Bale, W. F., and Balfour, W. M., Red cell and plasma volumes (circulating and total) as determined by radio iron and by dye. J. Exper. Med., 1942, 75, 221.
23. Gibson, J. G., 2nd, Aub, J. C., Evans, R. D., Peacock, W. C., Irvine, J. W., Jr., and Sack, T., The measurement of post-transfusion survival of preserved stored human erythrocytes by means of two isotopes of radioactive iron. (In preparation for publication.)

24. Gibson, J. G., 2nd, and Evelyn, K. A., Clinical studies of the blood volume. IV. Adaptation of the method to the photoelectric microcolorimeter. J. Clin. Invest., $1938,17,153$.

25. Gibson, J. G., 2nd, Weiss, S., Evans, R. D., Peacock, W. C., Irvine, J. W., Jr., Good, W. M., and Kip, A. F., The measurement of the circulating red cell volume by means of two radioactive isotopes of iron. J. Clin. Invest., 1946, 25, 616.

26. Hahn, P. F., Balfour, W. M., Ross, J. F., Bale, W. F., and Whipple, G. H., Red cell volume circulating and total as determined by radio iron. Science, 1941, 93, 87.

27. Hahn, P. F., and Meneely, G. R., Personal communication.

28. Hawkins, W. B., and Whipple, G. H., The life cycle of the red blood cell in the dog. Am. J. Physiol., 1938, 122, 418.

29. Shemin, D., and Rittenberg, D., Studies on the formation of heme and on the average life time of the human red cell. Federation Proceedings, 1946, Vol. 5, Part II, p. 153.

30. Ashby, W., Determination of length of life of transfused blood corpuscles in man. J. Exper. Med., 1919, 29, 267.

31. Wearn, J. T., Warren, S., and Ames, O., Length of life of transfused erythrocytes. Arch. Int. Med., 1922, 29, 527.

32. Denstedt, O. F., Changes in blood during storage. Canad. M. A. J., 1942, 46, 188.

33. Mollison, P. L., and Young, I. M., On the survival of the transfused erythrocytes of stored blood. Quart. J. Exper. Physiol., 1940, 30, 313.

34. Maizels, M., and Paterson, J. H., Survival of stored blood after transfusion. Lancet, 1940, 2, 417.

35. Loutit, J. F., Mollison, P. L., and Young, I. M., Citric acid-sodium citrate-glucose mixtures for blood storage; report to Medical Research Council from Southwest London Blood Supply Depot. Quart. J. Exper. Physiol., 1943, 32, 183.

36. Hahn, P. F., and Bale, W. F., Linear relationship between the circulating red cell mass and the venous hematocrit as determined by radioactive iron. Am. J. Physiol., 1942, 136, 314.

37. Gibson, J. G., 2nd, Seligman, A. M., Peacock, W. C., Aub, J. C., Fine, J., and Evans, R. D., The distribution of red cells and plasma in large and minute vessels of the normal dog, determined by radioactive isotopes of iron and iodine. J. Clin. Invest., $1946,25,848$. 